Original Research

\title{
UJI AKTIVITAS ANTIBAKTERI FRAKSI ETIL ASETAT DAUN JAMBU BIJI (Psidium guajava L.) TERHADAP BAKTERI PENYABAB KARIES GIGI Streptococcus sanguis
}

\author{
ANALYSIS ANTIBACTERIAL ACTIVITIES ETHYL ACETATE FRACTION OF SEED \\ LEAF (Psidium guajava L.) ON DENTAL BACTERIA OF DENTAL CARIES \\ Streptococcus sanguis
}

Ovysta Darsono $^{1 *}$, Sumantri $^{2}$

Farmasi, Universitas 17 Agustus 1945 Jakarta, Jakarta Utara, Indonesia, 14350

*E-mail: ovystad@gmail.com

$\begin{array}{lll}\text { Diterima: } & \text { Direvisi: 29/09/2019 Disetujui: 06/11/2019 }\end{array}$

\begin{abstract}
Abstrak
Jambu biji (Psidium guajava Linn.) adalah tanaman obat yang digunakan didaerah tropis dan subtropis untuk mengobati banyak gagguan kesehatan. Ekstrak daun jambu biji putih mengandung senyawa yang memiliki antibakteri. Namun dari fraksi daun jambu biji (Psidium guajava Linn.) saat ini belum diketahui khasiat antibakteri penyebab karies gigi yaitu Streptococcus sanguis. Uji aktivitas antibakteri dilakukan dengan difusi cakram (Kirby-bauer), dimana media Nutrient Broth yang sudah dibiakkan dengan bakteri Streptococcus sanguis dan diinkubasikan selama 24 jam. Kontrol positif menggunakan ampicillin, kontrol negatif menggunakan DMSO, serta sampel uji yakni fraksi etil asetat. Zona hambat diukur menggunakan jangka sorong millimeter. Uji lanjutan dengan mengukur KHM dari senyawa yang memiliki aktivitas tertinggi terhadap pertumbuhan bakteri, dilakukan dengan metode dilusi cair. Media Nutrien Broth yang sudah dibiaakkan S. sanguis diberikan konsentrasi ekstrak masing-masing $5 \%, 10 \%, 15 \%, 20 \%$ dan $25 \%$. Hasil penelitian menunjukan fraksi etil asetat daun jambu biji memiliki aktivitas dalam menghambat pertumbuhan bakteri dengan rerata zona hambat $16.00 \pm 0.719 \mathrm{~mm}$ pada bakteri $S$. sanguis. Dilanjutkan dengan uji KHM dengan nilai KHM $15 \%$. Uji kebocoran asam nukleat dan protein menunjukkan adanya kebocoran sel pada bakteri pada nilai $1 \mathrm{KHM}$ dan $2 \mathrm{KHM}$.
\end{abstract}

Kata kunci : Fraksi; Daun Jambu Biji; Psidium guajava Linn; Streptococcus sanguis

\begin{abstract}
Guava (Psidium guajava Linn.) is a medicinal plant used in tropical and subtropical regions to consume a lot of health benefits. White guava leaf extract contains compounds that have antibacterial properties. But from the guava leaffraction (Psidium guajava Linn.) At present there is no known antibacterial effect of dental caries, Streptococcus sanguis. The antibacterial activity test was carried out by disc diffusion (Kirby-bauer), where the Nutrient Broth media was cultured with Streptococcus sanguis bacteria and incubated for 24 hours. The positive control group used
\end{abstract}


ampicillin, the negative control group used DMSO, and the test sample was ethyl acetate fraction. The inhibition zone is measured using millimeter calipers. Further testing by measuring the MIC of the compound which has the highest activity against bacterial growth was carried out by liquid dilution method. Nutrient Broth media which have been cultivated by S. sanguis are given extract concentrations of 5\%,10\%,15\%,20\% and $25 \%$ respectively. The results showed that ethyl acetate fraction of guava leaves had activity in inhibiting the greatest bacterial growth with a mean inhibition zone of $16.00 \pm 0.719 \mathrm{~mm}$ in S. sanguis bacteria. Followed by MIC test with a MIC value of $15 \%$ for each bacterium. Leak test of nucleic acid and protein showed cell leakage in both bacteria at 1 MIC and 2 MIC values.

Keywords: Fraction; guava leaves; Psidium guajava Linn; Streptococcus sanguis

\section{PENDAHULUAN}

Penyakit karies gigi dan jaringan pendukung gigi (periodontal) umumnya disebabkan oleh plak gigi, yang sampai saat ini masih menjadi masalah utama dalam bidang kesehatan mulut dan gigi. Plak gigi adalah lengketan yang berisi bakteri dan produk-produknya yang terbentuk pada permukaan gigi [2].

Bakteri kariogenik merupakan bakteri yang memiliki kemampuan dalam menyebabkan karies. Bakteri ini meliputi Actinomyces, Lactobacillus, Streptococcus mutans dan Streptococcus sanguis. Streptococcus sanguis merupakan bakteri yang dapat berkolonisasi di permukaan gigi pada tahap awal pembentukan plak sehingga menyebabkan bakteri lain [7].

Jambu biji (Psidium guajava Linn.) adalah tanaman obat yang digunakan didaerah tropis dan subtropis untuk mengobati banyak gagguan kesehatan. Jambu biji (Psidium guajava Linn.) menunjukan bahwa daunnya memiliki antibakteri, hipoglikemik, antiinflamasi, analgesik, antipiretik [6].

Ekstrak daun jambu biji putih mengandung senyawa saponin, tanin, steroid, flavonoid, alkaloid dan triterpenoid [5]. Flavonoid dari isololat daun jambu biji memiliki antibakteri terhadap S. aureus dan E. Coli [9]. Namun dari fraksi daun jambu biji (Psidium guajava Linn.) saat ini belum diketahui khasiat antibakteri penyebab karies gigi yaitu Streptococcus sanguis. Berdasarkan paparan diatas maka peneliti ingin melakukan pengujian aktivitas antibakteri fraksi etil asetat terhadap bakteri penyebab karies gigi yaitu Streptococcus sanguis.

\section{METODE}

\section{Sampel (Bahan) Penelitian}

Bahan alam yang digunakan dalam penelitian ini adalah daun jambu biji yang diperoleh dari Balitro. Determinasi tanaman daun jambu biji (Psidium guajava L.) dilakukan di Lembaga Ilmu Pengetahuan Indonesia (LIPI). Bahan yang digunakan untuk ekstraksi, uji fitokimia, dan fraksi adalah etanol 96\%, aquadest, pereaksi Dragendorf, logam magnesium, amil alkohol, ammonia, reagen $\mathrm{FeCl}_{3}$, Bouchardat, etil asetat. Bahan uji aktivitas antibakteri yaitu media TSA, mrdia NB, DMSO, Natrium klorida, McFarland 0,5. Streptococcus sanguis di peroleh dari Laboratorium Kedokteran Universitas Indonesia. 


\section{Prosedur kerja}

\section{Ekstraksi}

Daun jambu biji dibersihkan dari kotoran lalu dikeringkan dan diblender menjadi sebuk. Serbuk diekstraksi dengan etanol 96\% dengan perbandingan 1 bagian bahan dan 6 bagian pelarut. Metode yang digunakan yaitu maerasi selama selama 3 x 24 jam. Lakukan pengocokan berputar tanpa membuka batol kaca 1 x 12 jam, Setelah 3 hari simplisia tersebut disaring menggunakan kertas saring. Ekstrak dipekatkan dengan rotary evaporator dan water bath.

\section{Fraksi Etil Asetat}

Ekstrak etanol ditimbang sebanyak 30 g dimasukkan kedalam gelas piala kemudian ditambahkan $20 \mathrm{~mL}$ aquadest dan $10 \mathrm{~mL}$ larutan etil asetat, lalu diaduk. Dimasukkan ke dalam corong pisah, didiamkan hingga terjadi pemisahan antara air dan etil asetat. Kemudian dikeluarkan air, dimasukkan ke dalam gelas piala dan etil asetat dimasukkan ke dalam vial sebagai ekstrak etil asetat. Ekstrak hasil fraksinasi dipekatkan dengan penangas air sehinngga diperoleh bentuk fraksi kental.

\section{Uji Aktivitas Antibakteri}

Uji aktivitas dilakukan terhadap bakteri Streptococcus sanguinis dengan menggunakan metode difusi cakram menggunakan kertas cakram. Pada media TSA yang sudah dicampurkan suspense bakteri, kertas cakram diletakkan di atas media TSA dan ditetesi larutan uji dengan konsentrasi $100 \%$. Ampisilin sebagai kontrol positifnya, dan kontrol negative digunakan aquadest steril. Kemudian diinkubasi pada suhu $37^{\circ} \mathrm{C}$ selama $18-24$ jam. Setelah itu diameter daerah hambat diukur menggunakan penggaris dan jangka sorong.

\section{Uji Konsentrasi Hambat Minimum}

Sebanyak $5 \mathrm{~mL}$ media NB steril dimasukan dalam tabung reaksi yang ditambkan $1 \mathrm{~mL}$ fraksi etil asetat daun jambu biji dengan konsentrasi (5\%, 10\%, 15\%, 20\% dan 25\%) dan bakteri uji dalam hal ini yaitu Streptococcus sanguis kemudian semua tabung reaski dihomogen kan dan diambil sebayak $2 \mathrm{~mL}$ untuk diukur nilai absorbansi Optical Density (OD) bakteri dengan menggunakan spektrofotometer UV-VIS $(\chi=600 \mathrm{~nm})$. Setelah itu tabung reaksi diatas diinkubasi selama 24 jam pada suhu $37^{\circ} \mathrm{C}$. Nilai OD pasca inkubasi diukur kembali dengan mengambil $2 \mathrm{~mL}$ untuk diukur nilai OD dengan menggunakan spektrofotometer UV-VIS $(\chi=600 \mathrm{~nm})$. Pada kontrol positif yang dipakai berisi media, suspense bakteri dan antibiotik ampisilin. Sedangkan pada kontrol negatif berisi media.

\section{Uji Kebocoran Protein dan Asam Nukleat}

Diambil suspensi bakteri yang akan diuji yaitu Streptococcus sanguinis yang sebelumnya telah diinkubasi selama 24 jam dalam media NB sebanyak $10 \mathrm{~mL}$ Kemudian lakukan sentrifus 
dengan kecepatan 10.000 g selama 15 menit. Selanjutnya filtrat dibuang dan pellet dalam tabung dicuci dengan buffer fosfat $\mathrm{pH}$ 7,0 sebanyak 2 kali.

Kemudian pellet disuspensikan kedalam larutan buffer fosfat dengan $\mathrm{pH}$ sebesar 7,0 ditambahkan larutan uji (fraksi). Kemudian inkubasi dalam shaker inkubator selama 24 jam. Kemudian suspensi bakteri disentrifuse selama 15 menit dengan kecepatan $10.000 \mathrm{~g}$ sehingga diperoleh filtrat yang selanjutnya diukur absorbansi dengan Spektrofotometer UV-Vis pada panjang gelombang $260 \mathrm{~nm}$ dan $280 \mathrm{~nm}$. Kontrol positif yang dipakai berisi media, suspense bakteri dan antibiotik ampisilin.

\section{HASIL DAN PEMBAHASAN}

Nilai rendamen yang didapatkan adalah $15,13 \%$ hasil ini sesuai dengan syarat yaitu tidak kurang dari $12.3 \%{ }^{3}$ Hasil identifikasi organoleptis ekstrak daun Jambu biji yaitu ekstrak kental berwarna hijau kehitaman dengan rasa pahit dan dengan bau yang khas dari simplisia. Hasil bobot dari ektrak kental fraksi etil asetat sebesar 4,9 g dari perbandingan $30 \mathrm{~g}$ ekstrak : $10 \mathrm{~mL}$ aquadest : $90 \mathrm{~mL}$ etil asetat lalu dipekatkan dengan rotary evaporator dan water bath. Uji antibakteri ekstrak fraksi etil asetat dilakukan triplo pada setiap sampel.

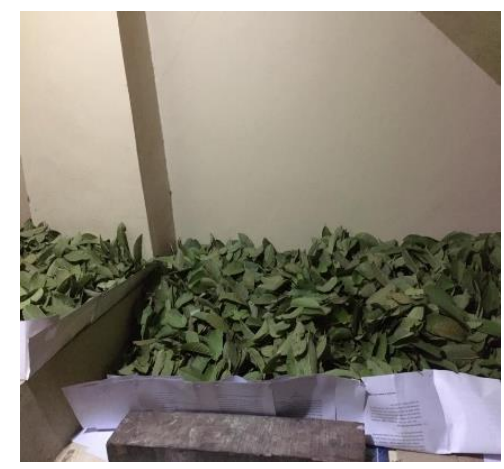

Gambar 1 Daun Jambu Biji

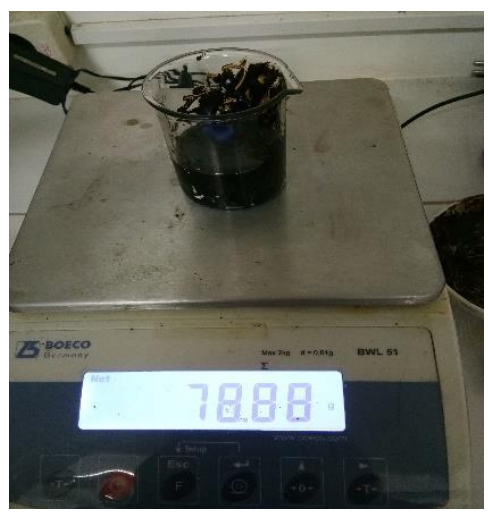

Gambar 2 Ekstrak Kental Daun Jambu Biji 


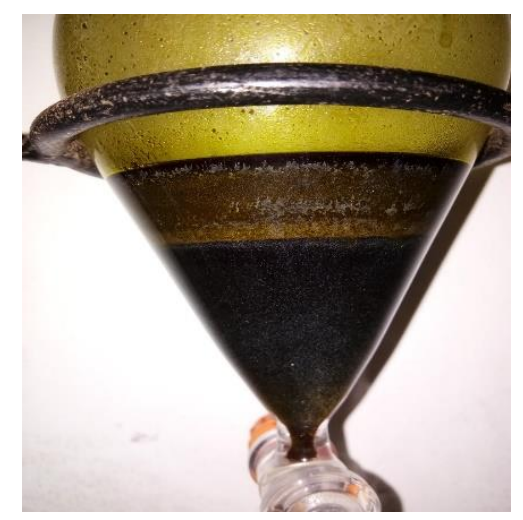

Gambar 3 Fraksinasi Etil Asetat Daun Jambu Biji

Tabel 1 Hasil Uji Antibakteri Ekstrak Fraksi Etil Asetat

\begin{tabular}{|c|c|c|c|}
\hline Pengulangan & $\begin{array}{c}\text { Kontrol } \\
\text { Negatif } \\
(\mathbf{m m})\end{array}$ & $\begin{array}{c}\text { Kontrol } \\
\text { Positif } \\
(\mathbf{m m})\end{array}$ & $\begin{array}{c}\text { Zona } \\
\text { Hambat } \\
(\mathbf{m m})\end{array}$ \\
\hline 1 & 0 & 20.18 & 15.62 \\
\hline 2 & 0 & 19.44 & 16.83 \\
\hline 3 & 0 & 19.46 & 15.55 \\
\hline Jumlah & 0 & 59.08 & 48.00 \\
\hline Diameter rata-rata (mm) & 0 & 19.69 & 16.00 \\
\hline SD & 0 & 0.421 & 0.719 \\
\hline
\end{tabular}

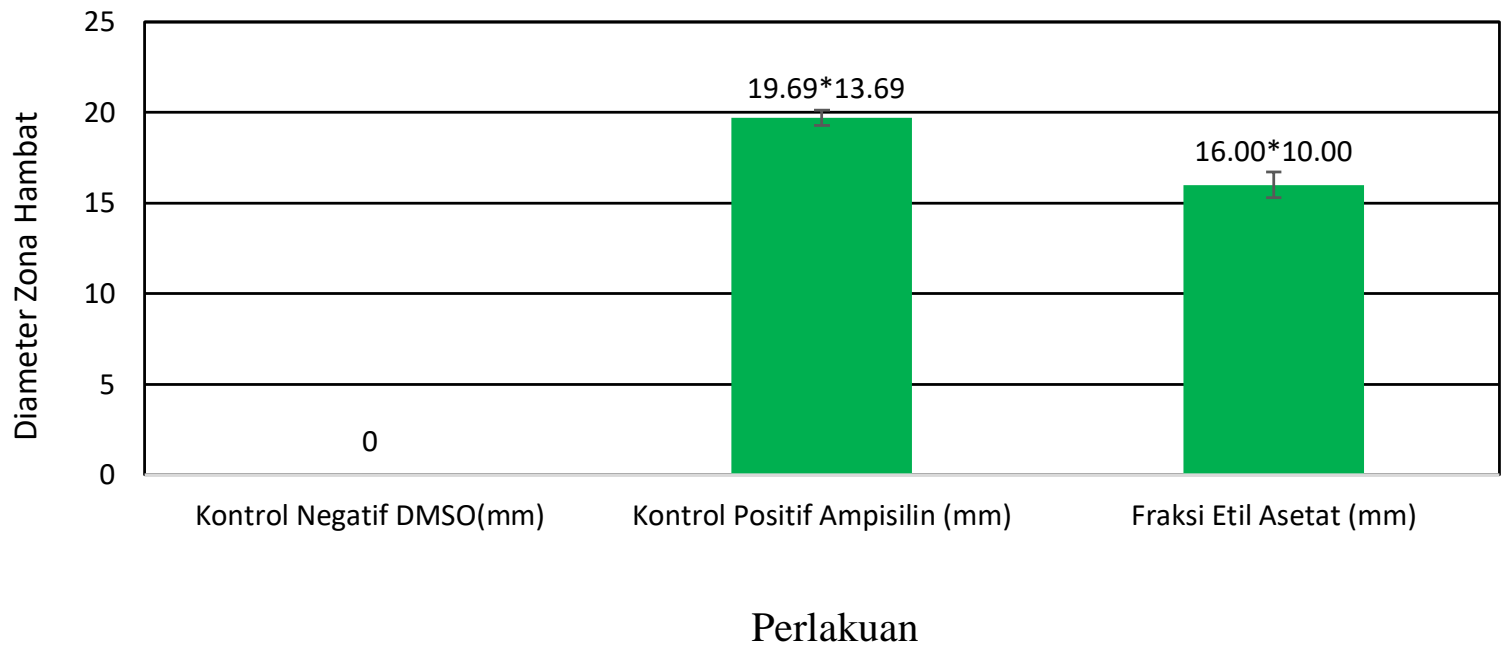

Gambar 4 Diagram Diameter rata-rata S. Sanguis 


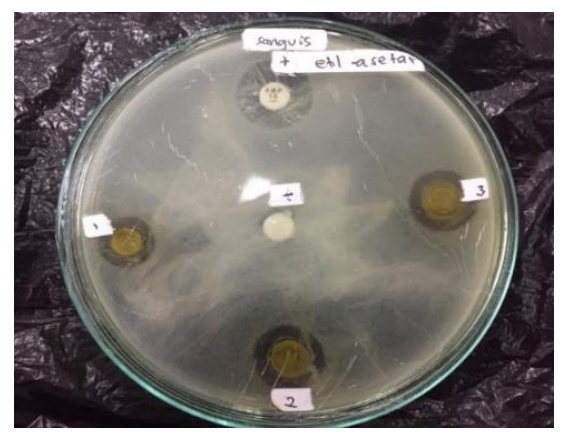

Gambar 5 Hasil Uji Aktivitas Bakteri S. Sanguis

Uji aktivitas antibakteri menunjukan bahwa sampel fraksi etil asetat daun jambu biji memiliki aktivitas sebagai antibakteri yang dapat dilihat dari zona hambat yang terbentuk. Terbentuknya zona bening merupakan bentuk penghambatan pertumbuhan terhadap bakteri. Hasil hambatan menjadi 4 kelompok zona hambat yaitu zona hambat yang lemah dengan diameter $\leq 5$ $\mathrm{mm}$, zona hambat sedang dengan diameter 5-10 mm, zona hambat yang kuat dengan diameter 10$20 \mathrm{~mm}$ dan zona hambat yang sangat kuat dengan diameteer $\geq 20 \mathrm{~mm}$. ${ }^{10}$ Berdasarkan dari penelitian yang dilakukan nilai rata-rata zona hambat yang didapat untuk bakteri dapat dikatakan sudah memasukin standar. Hasil uji aktivitas antibakteri pada ekstrak fraksi daun jambu biji adalah $16.00 \mathrm{~mm}$ tersebut termasuk dalam zona hambat kuat. Uji antibakteri fraksi daun jambu biji terhadap bakteri Streptococcus sanguis digunakan untuk membandingkan dengan penelitian sebelumnya yang menggunakan ektrak daun jambu biji terhadap bakteri Streptococcus mutan [8].

Hasil uji aktivitas antibakteri dari fraksi etil asetat daun jambu biji memberi pengaruh terhadap pertumbuhan bakteri Streptococcus sanguis oleh karena itu bisa dilanjutkan untuk mengetahui nilai konsentrasi hambat minumum (KHM) dari fraksi etil asetat daun jambu biji. Hasil dari KHM yang didapatkan dari konsentrasi $5 \%$ - $25 \%$ diperoleh nilai KHM $15 \%$ pada bakteri $S$. sanguis. Uji aktivitas antibakteri dari fraksi etil asetat daun jambu biji dilakukan triplo pada setiap sampel.

Tabel 2 Nilai OD dari Fraksi Etil Asetat Daun Jambu Biji Terhadap S. sanguis

\begin{tabular}{|c|c|c|}
\hline Konsentrasi & Rata-rata & SD \\
\hline Kontrol + & 0.008 & 0.004 \\
\hline Kontrol - & 0.203 & 0.006 \\
\hline $5 \%$ & 0.198 & 0.070 \\
\hline $10 \%$ & 0.184 & 0.026 \\
\hline $15 \%$ & 0.168 & 0.035 \\
\hline $20 \%$ & 0.067 & 0.002 \\
\hline $25 \%$ & 0.063 & 0.010 \\
\hline
\end{tabular}




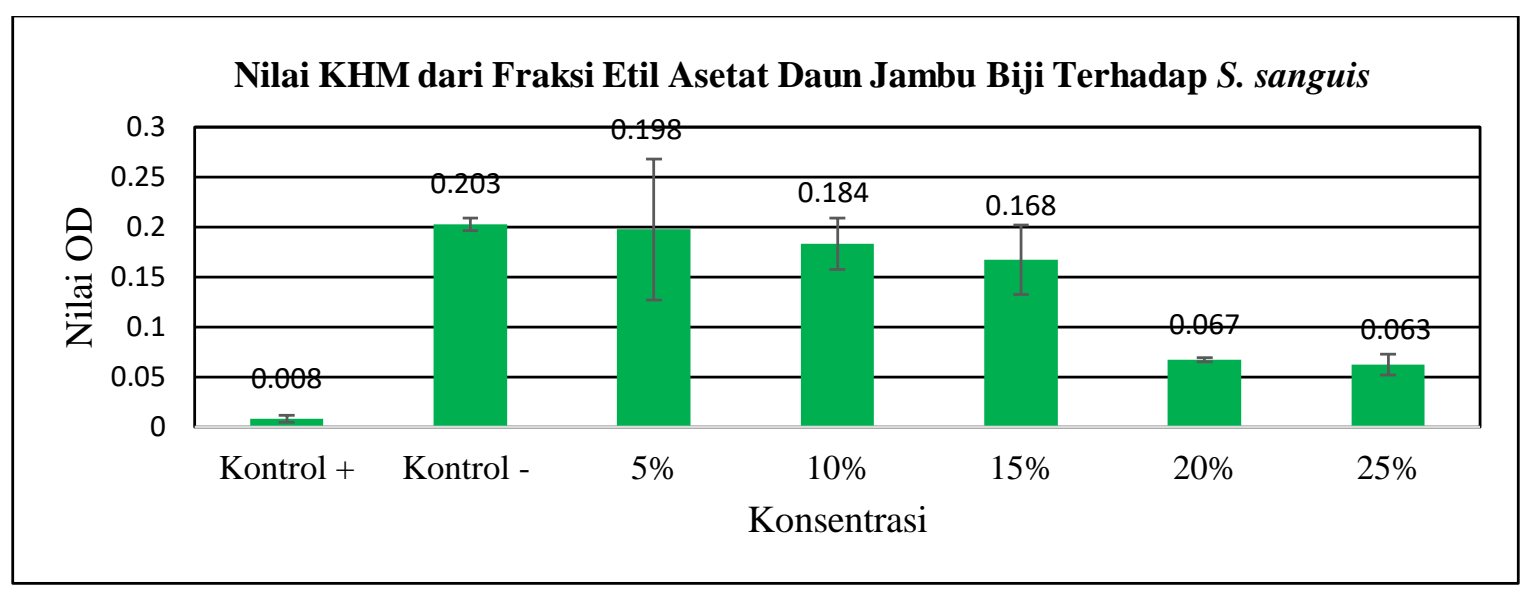

Gambar 6 Diagram Nilai OD dari Fraksi Etil Asetat Daun Jambu Biji Terhadap S. sanguis

Hasil uji aktivitas antibakteri dari fraksi etil asetat daun jambu biji memberi pengaruh terhadap pertumbuhan bakteri Streptococcus sanguis oleh karena itu bisa dilanjutkan untuk mengetahui nilai konsentrasi hambat minumum (KHM) dari fraksi etil asetat daun jambu biji. Uji KHM digunakan 5 varian konsentrasi dimana konsentrasinya adalah sebesar 5\%, 10\%, 15\%, 20\%, dan 25\% untuk masing-masing bakteri. Hasil dari KHM yang didapatkan dari konsentrasi $5 \%$ $25 \%$ diperoleh nilai KHM $15 \%$ pada bakteri S. sanguis. Pada konsentasi $15 \%$ ekstrak fraksi daun jambu biji memiliki selisih nilai absorbansi OD adalah nol, sehingga dapat diartikan terjadi penghambatan pertumbuhan bakteri. Konsentrasi 5\% masih terdapat pertumbuhan bakteri karena tingginya nilai absorbansi. Sedangkan pada konsentrasi $15 \%$ terjadi penurunan absorbansi yang signifikan yaitu 0,244. Hal ini dapat menunjukan bahwah pada konsentrasi $15 \%$ tidak ada pertumbuhan bakteri $S$. sanguis. Peningkatan absorbansi pada 1 KHM dan 2 KHM menunjukan terjadinya peningkatan kebocoran sitoplasma. Adanya kebocoran pada sel bakteri uji diduga diakibatkan oleh kandungan senyawa-senyawa pada fraksi. Uji konsentrasi hambat minumum (KHM) biji dilakukan triplo pada setiap sampel.

Tabel 3 Nilai OD Spektrofotometer Ekstrak Fraksi Etil Asetat Daun Jambu Biji Terhadap S. Sanguis

\begin{tabular}{|c|c|c|c|c|}
\hline \multirow{2}{*}{ Perlakuan } & \multicolumn{4}{|c|}{ Nilai } \\
\hline & $\mathrm{K}+(\mathrm{Amp} 10 \mu \mathrm{g})$ & K - (NB + Bakteri) & $1 \mathrm{KHM}$ & 2 KHM \\
\hline \multirow{3}{*}{ As. Nukleat } & 0.520 & 0.059 & 0.382 & 0.467 \\
\hline & 0.534 & 0.062 & 0.381 & 0.465 \\
\hline & 0.523 & 0.054 & 0.376 & 0.468 \\
\hline Rata-Rata & 0.526 & 0.058 & 0.380 & 0.467 \\
\hline SD & 0.007 & 0.004 & 0.003 & 0.002 \\
\hline \multirow{3}{*}{ Protein } & 0.712 & 0.043 & 0.487 & 0.616 \\
\hline & 0.765 & 0.037 & 0.486 & 0.614 \\
\hline & 0.700 & 0.051 & 0.481 & 0.613 \\
\hline Rata-Rata & 0.726 & 0.044 & 0.485 & 0.614 \\
\hline SD & 0.034 & 0.007 & 0.003 & 0.002 \\
\hline
\end{tabular}




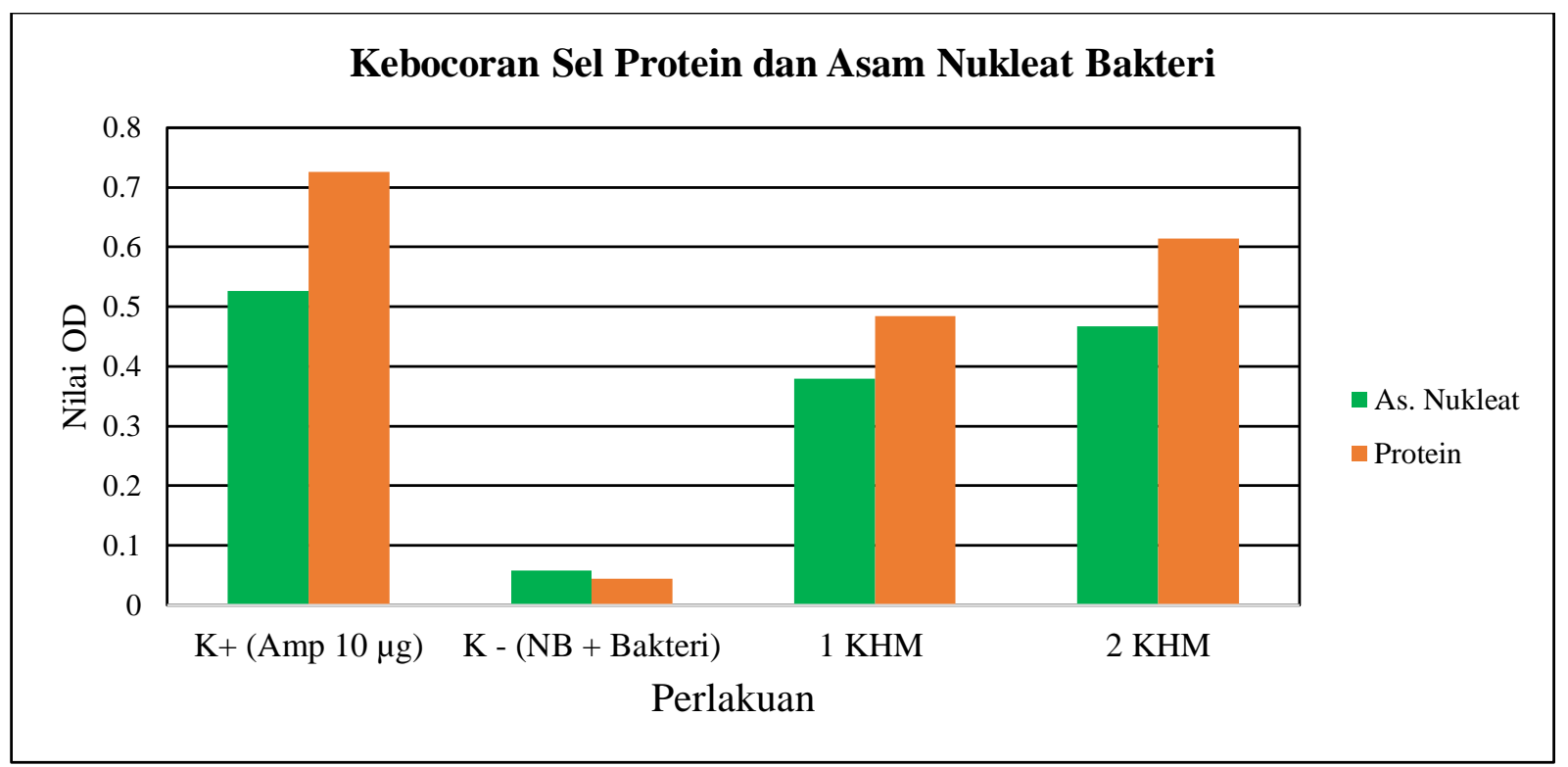

Gambar 7 Diagram Kebocoran Sel Protein dan Asam Nukleat Fraksi Etil Asetat Daun Jambu Biji terhadap S. Sanguis

Pemberian fraksi etil asetat daun jambu biji pada bakteri sesuai dengan KHM dapat mengakibatkan terjadinya kebocoran sel yang diamati dengan adanya kebocoran protein dan asam nukleat. Adanya kebocoran pada sel bakteri uji diduga diakibatkan oleh kandungan senyawasenyawa pada fraksi. Peningkatan absorbansi menunjukan terjadinya peningkatan kebocoran sitoplasma. Sesuai dengan penelitian sebelumnya jika semakin tinggi konsentrasi yang diberikan semakin tinggi nilai absorbansi yang terdeteksi dan semakin meningkatt kebocoran sel [4].

Mekanisme kerja flavonoid sebagai antibakteri dapat dibagi menjadi 3 yaitu menghambat sintesis asam nukleat, menghambat fungsi membran sel dan menghambat metabolisme energi. Mekanisme antibakteri flavonoid menghambat sintesis asam nukleat adalah cincin A dan B yang memegang peran penting dalam proses interkelasi atau ikatan hidrogen dengan menumpuk basa asam nukleat yang menghambat pembentukan DNA dan RNA. Flavonoid menyebabkan terjadinya kerusakan permeabilitas dinding sel bakteri, mikrosom,dan lisosom sebagai hasil interaksi antara flavonoid dengan DNA bakteri [1].

Berdasarkan pembahasan diatas menunjukan bahwa mekanisme dari flavonoid yang terdapat dalam daun jambu biji (Psidium guajava L) memiliki peran sebagai antibakteri terhadap bakteri $S$. sanguis. Mekanisme kerja zat aktif tersebut dapat menghambat sintesis dinding sel dan menghambat fungsi membran sel. Oleh karena itu penelitian ini perlu dilanjutkan untuk membuat bentuk sediaan antibakteri terhadap bakteri S.sanguis. 


\section{KESIMPULAN}

Adanya aktivitas antibakteri fraksi etil asetat daun jambu biji terhadap pertumbuhan bakteri Streptococcus sanguis sebesar 16,00 mm yang termasuk zona hambat yang kuat. Nilai KHM yang diperoleh dari ekstrak fraksi etil asetat daun Jambu biji terhadap pertumbuhan Streptococcus sanguis adalah pada konsentrasi $15 \%$.

\section{UCAPAN TERIMA KASIH}

Penulis mengucapkan terimakasih kepada Dekan dan Ketua Program Studi Farmasi yang telah memberikan kesempatan untuk berkarya di Kampus Universitas 17 Agustus 1945 Jakarta dan pihak-pihak lain yang telah mendukung dalam pembuatan jurnal penelitian ini.

\section{DAFTAR RUJUKAN}

1. Carolia, N., \& Noventi, W. Potensi ekstrak daun sirih hijau (Piper betle L.) sebagai alternatif terapi Acne vulgaris. Jurnal Majority. 2016. 5(1). 140-145.

2. Handayani F., Reksi S., Ria M.S. Formulasi dan Uji Aktivitas Antibakteri Streptococcus mutans dari Sediaan Mouthwash Ekstrak Daun Jambu Biji (Psidium guajava Linn.). Akademi Farmasi, Samarinda. 2017.

3. Kemenkes RI. Farmakope Herbal Indonesia Edisi I. Penerbit Menkes RI. Jakarta. 2009.

4. Madduluri S, Babu S, In Vitro Evaluation Of Antibacterial Activity Of Five Indigenous Plants Extract Against Five Bacterial Pathogens Of Human. Internasional Journal Of Pharmacy And Pharmasetical Sciences. 2013, 5 (4):679-684.

5. Maulana, E. A., Asih, I. A., \& Arsa, M. Isolasi dan Uji Aktivitas Antioksidan Senyawa Flavonoid dari Ekstrak Daun Jambu Biji Putih (Psidium guajava Linn). Jurnal Kimia. 2016.

6. Oktiarni D, Manaf S, Suripno. Pengujian Ekstrak Daun Jambu Biji (Psidium guajava linn) Terhadap Penyembuhan Luka Bakar pada Mencit (Mus musculus). Fakultas Matematika dan Ilmu Pengetahuan Alam. Bengkulu; 2012. 8(1).

7. Santoso, T. B., \& Budi, H. T. Pengaruh Seduhan Teh Hijau (Camellia Sinensis) Terhadap Hambatan Pertumbuhan Bakteri Streptococcus Sanguis Penyebab Karies (In Vitro), Doctoral dissertation. Universitas Muhammadiyah Surakarta, 2017.

8. Tampedje, A. A, Uji efek antibakteri ekstrak daun jambu biji (Psidium guajava Linn.) 
terhadap pertumbuhan koloni Streptococcus mutans. PHARMACON, 2016, 5(3).

9. Ukwueze, S. E., Osadebe, P. O., \& Okoye, F. B. A new antibacterial benzophenone glycoside from Psidium guajava (Linn.) leaves. Natural product research, 2015. 29(18). 1728-1734.

10. Wijaya, I., Valerian, A., Purba, M. H., Dalmasius, D., Girsang, E., \& Nasution, S. W. Uji Perbandingan Antibakteri Antara Ekstrak Daun Mangkok (Nothopanax scutellarium) dengan Antibiotik Ciprofloxacin Terhadap Staphylococcus aureus. SCIENTIA JOURNAL. 2018. 7(2). 176-181. 